\title{
THE INFLUENCE OF AFLATOXINS ON PREVALENCE OF NEONATAL JAUNDICE IN QUALYOBIA GOVERNORATE, EGYPT
}

\author{
BY \\ Mohamed El-Shishtavy*; Ragia Hegazy*; Nermin A. Hasan*, \\ Soha Abd El-Hady**; Elham Shewy \& Sahar A. El-Dakroury \\ Deparments of *Forensic Aledicine and Clinical Toxicology** and Pediatrics, \\ Benha University and Alansoura Unicersity. Egypt
}

\begin{abstract}
Background: Aflatoxins(AF) are commonly environmental toxicant in developing tropical contries. Aim of the work: This sudy set out to investigate the prevalence of aflatoxins and their metabolites in scra of jaundiced neonates and their moher's sera and breast milk using Thin Layer Chronatography (TLC). Subjects and methods: Samples svere obtained from 200 jaundiced neonates and their mothers. and 60 non jaundiced consrols and their mothers admitted to Benha university huspital, Jocated in Qual. yobin governorate, Egypt. Results: AF levels in cases were highty significant $(P<0.001)$ comparing with controls, the highest percentage of aflatoxin type in the studied groups was for $\mathrm{Mll}$, then $\mathrm{Al} / 2$ then BI respechively but no correlation besween severity of jaundice and aflatoxins levels. There was significant negative correlation $(P<0.001)$ in birh weight with afatoxin level in jaundiced neonates. The rates of detecrion of aflatoxins in neonates were: significant higher $(P<0.001)$ in breast feeding than bothle feeding neonates, significant higher $(P<0.00 I)$ in hot wet than dry cold months and significant higher $(P<0.05)$ in samples from those living in rural than urban areas. Conchusion: aflatoxins are risk factor for neonatal jaundice and low birth weight in hot wet months in those fiving in rural areas.
\end{abstract}

Keywords: Aflatoxins, Neonatal jaundice, Qualyobia

\section{INTRODUCTION}

Aflatoxins are secondary metabolites produced by some species of filamentous fungi called aspergilli. The major aspergillus species of fungi that can produce aflatoxins are Aspergillus flavus and Aspergillus parasitic, both of which are found worldwide. These molds are ubiquitous in nature and accordingly contaminale a wide variety of loods and feeds and grow on a variely of substrates, thereby producing aflatoxins. The most biologically potent toxin of this group is aflatoxin B1 (AFB1) (Van Ness et. al., 1998). 
Aflatoxins are detected as natural contaminants of food and other agricultural commodities. Aflatoxins may enter food either by direct contamination as a result of molds growth on the food or by indirect contamination through the use of contaminated ingredients in the processed food or by using animal product as milk and milk products that contain aflatoxin residues caused by giving moldy meal to animals (Li et al., 2002).

Corns and peanut represent the major potentially contaminated commodities especially in tropical climatic conditions which favor fungal growth and legation of secondary metabolites. Aflatoxins occurred in noteworthy amounts in market place samples of edible nuts and grains as well as their derived products and figs (Agnes and Akabarska, 2003).

Although, aflatoxins (AF) were known for more than 30 years, there is still considerable controversy about their human effect. Food- borne exposure to aflatoxins B1 (AFB1) has implicated in association with acute hepatic injury in humans as well as carcinogenesis (Sudakin, 2004).

During the last decade, a lot of epidemiological and laboratory investigations have shown a closed association between dietary exposure of pregnant women to aflatoxins and increased incidence of neonatal jaundice (Wild et. al, 2001).
Wild and Turner (2002) reported that aflatoxins play a role in induction of neonatal physiological jaundice in some tropical countries where the level of AF is high. Bakry et al. (1993) detected six types of aflatoxins (AFB1, AFB1+AFG1, AFM1, AFM2, AFG1 and AFG2) in 22 out of 200 breast milk samples (11\%) collected from Qualyobia governorate, Egypt. Moreover, the same authors examined forty samples of children's blood (1-15 years old), where all contained AFB1.

The progressive increase in number of neonatal physiological jaundice in Egypt has attracted the attention to study the effect of some factors including food habits that could implicated in the pathogenesis of such condition.

This study is designed to investigate the prevalence of aflatoxins in the blood of neonates with physiological jaundice and their mothers in order to determine the possible relationship between perinatal aflatoxins exposure and unexplained neonatal jaundice anci low birth weight.

\section{SUBJECTS AND METHODS}

\section{Subjects}

This study was conducted on 260 neonates and their mothers. The subjects were divided into two groups. All neonates were selected from outpatient clinics in Benha University Hospital, Pediatric De- 
partment, Neonatology unit tocated in Qualyobia governorate, Egypt.

Group I: This group included 200 full term neonates with physiological jaundice. This group contained 134 males and 66 females with age ranged from 3-5 days, and their mothers.

Group II: (control group): This group included 60 healthy neonates with normal bilirubin level. This group contained 30 males and 30 females with age ranged from 3-5 days, and their mothers.

Ethical approval was obtained from the parents of the neonates underwent this study. Informed consent was also taken from all mothers taking part in this study.

In this study all cases and controls were subjected to:

I) Questionnaire to collect relevant data regarding time of neonatal birth at 4 months of 2006 (cold dry months i.e. Jan. and Feb. and hot wet months i.e. Aug. and Sept.), their residence and neonatal diet habit whether breast feeding or bottle feeding. Also questionnaires were asked to their mothers about medical history (to exclude infectious diseases, chronic disease and drugs intake during pregnancy) and full dietetic history were taken from all mothers especially aflatoxins contaminated food (i.e. cereals foods, milk, milk products, etc).

II) Careful physical examination: gestational age assessment by Ballard's score, birth weight and local organ examination to exclude any other causes of pathological jaundice.

III) Laboratory investigation: blood samples were obtained from neonates and their mothers. Breast milk samples were obtained from each study case and control. These samples were used for evalualion of aflatoxin and serum billirubin levels.

\section{Exclusion criteria:}

* Mother with any acute or chronic illness.

* Neonate with pathological jaundice.

* Neonate with any congenital anomalies.

* Preterm neonate.

\section{Methods:}

A-Serum bilinibin: $2-3 \mathrm{ml}$ of neonatal venous blood samples under sterile aseptic condition were withdrawn and left to clot for 2 hours at room temperature, centrifuged for 10 minutes at $5000 \mathrm{rpm}$ then serum separated and kept at $-20^{\circ} \mathrm{C}$ till the time of analysis (Whitington and Alonso, 2003).

\section{$B$-Aflatoxins determination:}

(1) Aflatoxin standaids: aflatoxins B1, B2, 
B1, G1and G2 together with their metabolites M1, M2, M2a, Q and Ro were obtained from sigma chemical company (Sigma Aldrich Corporation), P.O. Box 14508, St. Louis, Missuria, 63178 , USA).

(2) C18 sep. Pak.: These packs were obtained from Associates Inc. Milford, MAO, 1757, USA.

(3) Confirmatory tests of major aflatoxins and their metabolites in the blood and milk samples of all cases and controls were carried out by TLC as described by Petrson and Ciegler (1976).

(4) Quantitative determination of aflatoxins: positive samples and standard spots were measured with flurodetometer then the amount of each aflatoxin present in blood and milk samples were calculated (Pryzbylski, 1975).

Satistical methods (Wayne, 1995):

The methods used for statistical analysis of the collected data were the following:

1- t-test: for comparison between two means \pm standard deviations. P values less than 0.05 is considered significant.

2- One way ANOVA test (F test) for comparison between more than two means \pm standard deviations.

\section{RESULTS}

Two hundred and sixty neonates and their mothers were selected, 200 of them served as cases and 60 as controls, to determine the aflatoxin levels in neonatal and maternal blood and breast milk.

There was a high significant level ( $\mathrm{P}<$ 0.001 ) of aflatoxin in blood of neonates with neonatal jaundice and their maternal blood and breast milk compared with controls (Table 1 \& Fig. 1). In jaundiced neonates (cases), aflatoxin $\mathrm{M} 1$ was the highest percent $(81.5 \%)$, M2 was less common $(68.9 \%)$ while the least incidence was aflatoxin B1 $(67.5 \%)$. But in controls, AFM2 was the highest percent $(31.1 \%)$ followed by AFB1 (30\%) then AFM1 (18.5\%) (Table 2 ). There was no correlation between levels of neonatal blood aflatoxins and billiribin $(P>0.05)$ (Table 3$)$.

There was a highly significant ( $P<$ 0.001 ) reduction in birth weight of jaundiced neonates in comparison with controls (Table 4 \& Fig. 2). Also, there was a negative significant correlation $(\mathrm{P}<0.001)$ between aflatoxin levels and birth weight (Table 5 \& Fig. 2).

There was a highly significant correlation $(\mathrm{P}<0.001)$ between aflatoxin levels 
and breast feeding neonates in comparison with bottle feeding neonates (Table 6 \& Fig. 3). Aflatoxins level were highly significant $(\mathrm{P}<0.001)$ in hot humid months (Aug. and Sept.) when compared with cold dry months (Jan. and Feb.) (Table 7 \& Fig. 3). Additionally, there was significant correlation between aflatoxin levels and residence from rural areas than those from urban areas (Table 8 \& Fig. 3).

\section{DISCUSSION}

Human exposure to aflatoxins may begin prenatal, during breast feeding and continues in adult life. It's postulated that aflatoxins play a role in kwashirkor, increase neonatal susceptibility to infection and malignancy (Abdulrazzaç et al., 2004 ; Maxwell, 1998).

Aflatoxin levels in human and pet foods may not exceed $20 \mathrm{ppb}$, and aflatoxin levels in other animal feeds may not exceed 300 ppb (Theresa Lee, 2002).

This study was set out to investigate the prevalence of aflatoxins in the sera of babies with neonatal jaundice and their mothers in order to determine whether they contribute to the occurrence of unexplained neonatal jaundice in Qualyobia governate, Egypt. In the present study aflatoxins were significantly detected in neonatal blood, maternal blood and breast milk in studied cases compared with con- trols. There was no correlation of aflatoxins concentration in neonatal blood or maternal blood and severity of jaundice. These results coincide with Ahmed et al. (1995) who reported that aflatoxins were detected in blood over $50 \%$ of neonates with jaundice of unknown aetiology and there was no correlation between level of bilirubin and aflatoxins levels.

This is in agreement with Jonsyn et al. (1999) who found that $58 \%$ of cord samples from pregnant women from Sierra leone contained aflatoxins.In Ibadan, aflatoxins were detected in the blood of $27.4 \%$ of jaundiced infants. In Kenya, 53\% of women seen at hospital were found to be positive for aflatoxins at anytime during pregnancy and $37 \%$ of cord blood contained aflatoxins. In Thailand, $48 \%$ of cord blood samples were found to contain aflatoxins.

These results were in disagreement with that of another study done by Abdulrazzaq et al., (2004) who failed to demonstrate any effect of aflatoxins on ineonatal jaundice. They reported that there was no association between aflatoxin (M1) concentration in maternal blood or cord blood and jaundice or infection.

In a trial to explain the possible mechanism of aflatoxin in induction of neonatal jaundice, AAPSH (2004) reported that the liver was the principal target organ for 
toxicity. The liver is the predominant site of metabolic transformation of AFB1. Cytochrome $\mathrm{P}-450$ and $1 \mathrm{~A} 2$ catalyze the epioxidation of AFB1 to a highly reactive intermediate AFB1 exo-8, 9-epioxide (Guengerich et al., 1998). This intermediate binds with high affinity to guanine bases in DNA to form guanyl -N7 adducts (Guengerich, 2001). The formation of DNA adducts explains the toxic dynamic effects of AFB1. Acute cytotoxic effects of high-level AFB1 exposure may be mediated by binding to functional cellular protein. El-Gibaly et al. (2003) and Sudakin (2004) reported that in neonates hepatic excretory capacity is low because of low concentration of the binding protein liganid in hepatocytes and because of low activity of glucoronyl transferase.

In the present study, there was significant reduction in birth weight of neonatal jaundice compared with controls. Also, a highly significant negative correlation $(\mathrm{P}<0.001)$ was found between level of aflatoxins and birth weight especially in breast feeding neonates born in hot wet months. In accordance with these findings Abulu et al., 1995 and Hendrickse, 1997 found that aflatoxins exposure in tropical areas occur in $30 \%$ of pregnancies resulting sometimes in high levels of aflatoxins in cord blood, leading in turn to jaundice and possibly low birth weight and perinatal death. The biochemical, immunological and metabolic derangements caused by af- latoxin in the fetus could lead to low birthweight and intrauterine growth retardation (Bruce, 1994, Sodeindo et al., 1995). On the other hand Maxwell et al., (1994) failed to demonstrate any effect of aflatoxins on birth weight.

The concentration and frequency of plasma aflatoxins present in pregnant women delivering in hot wet months (August and September) was significantly higher than those delivering in dry months (January and February). The pattern of seasonal variation for detection of aflatoxins probably reflecting the ingestion of contaminated grains stored in summer when humidity and temperature are very high which favor fungal growth. This finding is in agreement with the result of studies done by Abdullrazzaq et al. (2004) and Osman et al. (1999) who explained the seasonal variation and the frequency of aflatoxins detected by the high contamination of foods during periods of high humidity and temperature. But Allen et al. (1992) were disagreeing with this result.

From our results we noticed that the higher percentage and concentrations of aflatoxins were present in rural areas than in urban areas in examined samples. This may be due to the improper storage of cereals which lead to growth of the fungus and the formation of the toxin. The bad behavior of farmers in rura areas in using this contaminated cereals in their food 
were noticed in most of positive cases and recorded in history of our cases during the questionnaire.

Boutrif and Canet (1998) had suggested that the possibility of removing the potential carcinogen aflatoxin from environment is certainly difficult. The progressive urbanization occurring in developing countries may afford an opportunity of determining whether the liver cancer is decreasing with urbanization and the changes in food habits and source of die tary staples while Olubuyide et al. (1994) proved that there was very little variation between the rural and urban populations sampled with slight higher level in rural areas.

In conclusion : This study demonstrates that the serum aflatoxinss are risk factors for neonatal jaundice occured in the wet hot months. There was also a strong negative correlation between afaltoxins and birthweight but there was no correlation between aflatoxin concentration and severity of hyperbillirubinemia.

Further studies are in need to: $\{1\}$ determine the extent of pre and postnatal exposure to aflatoxins and their effects on fetal and neonatal health, $\{2\}$ long term exposure to aflatoxins in childhood is necessary especially in areas where protein-energy malnutrition is endemic, (3) the modifying effect of dietary intake of lipotropes, proteins or vitamins on aflatoxins, $\{4\}$ identification of biological markers of exposure and toxicosis as the presence of aflatoxins in human blood and tissues and, $\{5\}$ the methods and mechanisms responsible for modulation and protection of neonates from aflatoxins exposure. 
El-Shishtawy et al...

Table (1) : Comparison of aflatoxins level in neonatal blood of jaundiced neonates, and their maternal blood and breast milk compared with controls.

\begin{tabular}{|c|c|c|c|}
\hline $\begin{array}{l}\text { Aflatoxin } \\
(\mathrm{ng} / \mathrm{ml})\end{array}$ & $\overline{\mathrm{X}} \pm \mathrm{SD}$ & $t$ & $\mathbf{P}$ \\
\hline $\begin{array}{l}\text { 1- Neonatal blood: } \\
\text { cases } \\
\text { controls }\end{array}$ & $\begin{array}{l}2.83 \pm 1.38 \\
0.16 \pm 0.02\end{array}$ & 19.47 & $<0.001$ \\
\hline $\begin{array}{l}\text { 2-Maternal blood: } \\
\text { cases } \\
\text { controls }\end{array}$ & $\begin{array}{l}2.8 \pm 1.38 \\
0.16 \pm 0.02\end{array}$ & 19.7 & $<0.001$ \\
\hline $\begin{array}{l}\text { 3-Breast milk: } \\
\text { cases } \\
\text { controls }\end{array}$ & $\begin{array}{l}2.55 \pm 1.32 \\
0.12 \pm 0.02\end{array}$ & 18.4 & $<0.001$ \\
\hline
\end{tabular}

Table (2): The percentage of different types of aflatoxins (AF)detected in studied groups (St. Gp.).

\begin{tabular}{|c|c|c|c|c|c|c|c|c|}
\hline \multirow[t]{2}{*}{$A F \backslash S t . G p$} & \multicolumn{2}{|c|}{ Cases } & \multicolumn{2}{|c|}{ Controls } & \multicolumn{2}{|c|}{ Total } & \multirow[t]{2}{*}{$z$} & \multirow[t]{2}{*}{$\mathbf{P}$} \\
\hline & n. & $\%$ & $\mathbf{n}$ & $\%$ & n & $\%$ & & \\
\hline M1 & 132 & 81.5 & 30 & 18.5 & 162 & 100 & 7.3 & $<0.001$ \\
\hline M2 & 40 & 68.9 & 18 & 31.1 & 58 & 100 & 2.2 & $<0.05$ \\
\hline B1 & 28 & 57.0 & 12 & 30 & 40 & 100 & 1.95 & $<0.05$ \\
\hline Total & 200 & 76.9 & 60 & 23.1 & 260 & 200 & & \\
\hline
\end{tabular}


El-Shishtawy et al...

Table (3): The correlation between blood aflatoxins (Bl/ AF) and serum bilirubin (S.Bil.) levels in jaundiced neonates.

\begin{tabular}{|l|c|c|c|}
\hline \multicolumn{1}{|c|}{ BI.AF.I S. Bil. } & $\overline{\mathrm{X}} \pm \mathbf{S D}$ & $\mathbf{t}$ & $\mathbf{P}$ \\
\hline $\mathbf{M} 1$ & $8.01 \pm 2.82$ & $\mathrm{t} 1=0.058$ & $>0.05$ \\
$\mathbf{n}=\mathbf{1 3 2}$ & & $\mathrm{T} 2=0.15$ & $>0.05$ \\
\hline $\begin{array}{l}\text { M2 } \\
\mathbf{n}=\mathbf{4 0}\end{array}$ & $8.39 \pm 2.48$ & $\mathrm{~T} 3=0.26$ & $>0.05$ \\
\hline $\mathbf{B} 1$ & & \\
\hline $\mathbf{n}=\mathbf{2 8}$
\end{tabular}

One way ANOVA, $\mathrm{F}=.014$

! $=\mathrm{MIVs}$ M2, $\mathrm{t} 2=\mathrm{M} 1 \mathrm{VsB} 1, \quad \mathrm{~B}=\mathrm{M} 2 \mathrm{Vs} \mathrm{B} 1$

Table (4) :Comparison between reduction of birth weight (B.W.) among cases and controls.

\begin{tabular}{|l|c|c|c|}
\hline \multicolumn{1}{|c|}{ St.Gp.। B.W. } & $\overline{\mathrm{X}} \pm \mathrm{SD}$ & $\mathrm{t}$ & $\mathbf{P}$ \\
\hline$\underline{\text { Cases }}$ & $2542.6 \pm 567.1$ & & \\
$\mathbf{n}=\mathbf{2 0 0}$ & & 8.01 & $<0.001$ \\
$\underline{\text { Controls }}$ & $3120 \pm 244.1$ & & \\
$\mathbf{n}=60$ & & & \\
\hline
\end{tabular}

Tablc (5): The correlation between aflatoxin levels and birth weight in jaundiced neonates.

\begin{tabular}{|l|c|c|c|}
\hline B.W Weonatal AF & $\bar{X} \pm$ SD & t & P \\
\hline $\mathbf{L B W}$ & $3.32 \pm 0.69$ & 9.85 & $<0.001$ \\
$\mathbf{n}=\mathbf{1 3 2}$ & $1.3 \pm 1.14$ & & \\
$\begin{array}{l}\text { Normal Wt. } \\
\mathbf{n}=68\end{array}$ & & & \\
\hline
\end{tabular}


Table (6): The correlation between aflatoxins level and types of neonatal fecding habit $(\mathrm{FH})$ in jaundiced neonates.

\begin{tabular}{|l|c|c|c|}
\hline \multicolumn{1}{|c|}{ FH $\backslash N$. AF } & $\overline{\mathrm{X}} \pm \mathrm{SD}$ & $\mathbf{t}$ & $\mathbf{P}$ \\
\hline Breast feeding & $3.7 \pm 0.62$ & & \\
$\mathbf{n}=118$ & $1.59 \pm 1.21$ & 10.3 & $<0.001$ \\
Bottle fecding & & & \\
$\mathbf{n}=82$ & & & \\
\hline
\end{tabular}

Table (7): The correlation between aflatoxins level and seasomal variation (SV) in jaundiced neonates.

\begin{tabular}{|l|c|c|c|}
\hline SV IN. AF & $\bar{x} \pm$ SD & t & P \\
\hline $\begin{array}{l}\text { Hot wet months } \\
\text { (Aug. \& Sep.) }\end{array}$ & $3 \pm 100$ & 7.02 & \\
\\
$\begin{array}{l}\text { Cold dry months } \\
\text { (Jan. \& Feb.) } \\
n=100\end{array}$ & $1.12 \pm 1.14$ & & \\
\hline
\end{tabular}

Table (8): The correlation between aflatoxins level and residence in jaundiced neonates.

\begin{tabular}{|l|c|c|c|}
\hline Residence IN. AF & $\bar{X} \pm$ SD & t & P \\
\hline Rural & $8.60 \pm 2.5$ & 2.31 & $<0.05$ \\
$n=150$ & $7.50 \pm 1.9$ & & \\
Urban & & & \\
\hline
\end{tabular}


El-Shishtawy et al...

Fig(1) Percentage of different types of aflatoxins among cases and controls

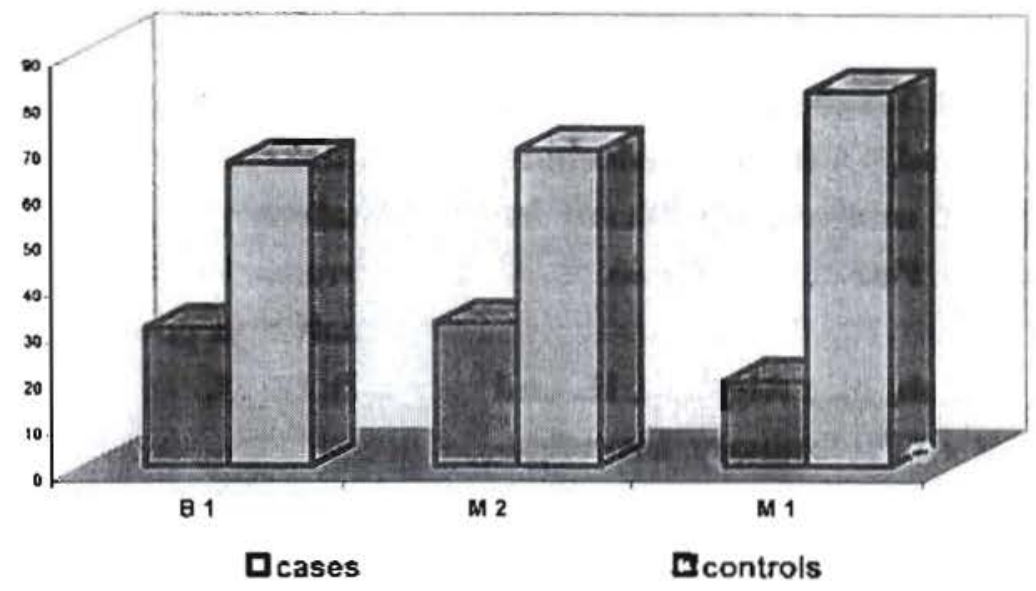

Fig. (2) Reduction in body welght among jaundiced neonates in cases and controls

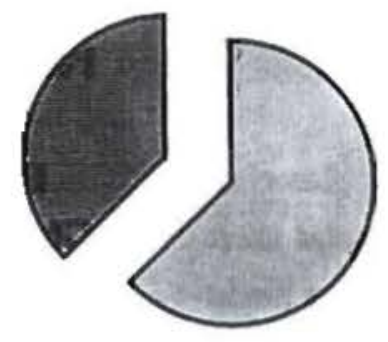

acases

a controls

Fig (3)Correlation of aflatoxins level and type of feeding, date of birth and residence in jaundiced neonates

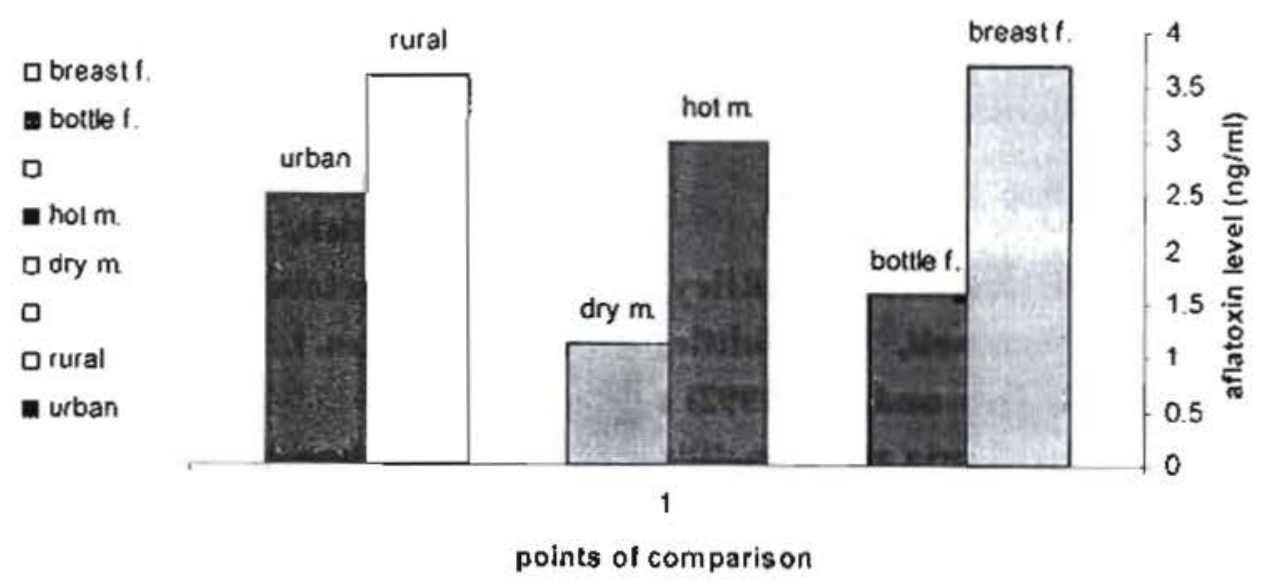

Mansoura J. Forensic Med. Clin. Toxicol.

Vol. XIV, No. 2, July 2006 


\section{REFERENCES}

Abdulrazzaq, X. M.; Osman, N. iyousif, Z. and Trad, O. (2004) : "Morbidity in neonates of mothers who have ingested aflatoxins". Ped. J., 24: 145-46.

Abulu, E. ; Uriah, N. ; Aigbefa, H. and Bboh, P. (1995) : "Preliminary investigation on aflatoxin in cord blood of jaundiced r.eonates". West Afr. J. Med., 17 (3): 184-7.

Agnes, V. and Akabarska, M. (2003): "Spermatotoxic effect of aflatoxin B1 in albino rats". Food Chem. Toxicol. J., 41(1): 119-30.

Ahmed, H. ; Hendrickse, R. ; Maxwell, S. and Yakubu, A. (1995): "Neonatal jaundice with reference to aflatoxins: an aetiological study in Zaeria, northern Nigeria". Ann. Trop. Ped. J., 15(1): 11-20.

AAPSH (American Academy of Pediatrics Subcommittee on Hyperbilirubinemia) (2004) : "Management of hyperbilirubinemia in the newborn infant 35 or more weeks of gestation". Ped. J., 114 (1): $297-$ 316.

Allen, S.; Wild, C.; Wheeler, J.; Riley, E.; Montesano, R.; Bennett, S.; Whittle, H.; Hall, A. and Greenwood, B. (1992) : "Aflatoxin exposure, malaria and hepatitis B infection in rural Gambian children".
Trans. R.Soc. Trop. Med. Hyg. 86 (4): 426430.

Bakry, H.; Abosalem, M.; ElShabrawy, R. and Elham E. (1993): "Occurrence of aflatoxins in breast milk in Qualyobia governate". Benha Vet. Med. J., 4(2): 88-93.

Boutrif, E. and Canet, C. (1998): "Mycotoxins prevention and controls: FAO programmes". Rev. E. Med. Vet. J., 149:681-91.

Bruce, R. (1994) : "Neonatal risk assessment for intrauterine aflatoxin exposure". Ped. J., 14:897.

El Gibaly, I.; Meki, A. and Abdel Ghaffar, S. (2003): "Novel - melatonin loaded chitosan microcapsules: in vitro characterization and antiapoptosis efficacy for aflatoxin $\mathrm{B} 1$ induce apoptosis in rat liver". Int. Phamacol. J., 261(1): 5-22.

Guengerich, F. L.; Johnson, W. and Shimada, T. (1998): "Activation and detoxification of aflatoxin B1". Mutatox. Res. J., 402:121-128.

Guengerich, F. L (2001) : "Forging the links the metabolism and carcinogenesis". Mutatox. Res. J., 488:195-209.

Hendrickse, R. G. (1997) : "Of sick turkeys, kwashiorkor, malaria, perinatal mor- 
tality, heroin addicts and food poisoning: research on the infleunce of aflatoxins on child health in tropics". Ann. Trop. Med. Parasitolo. J., 91 (7): 787-93.

Jonsyn, F.; Maxwell, S. and Hedrickse, R. (1999) : "Fetal exposure to ochratoxin A and aflatoxins". Ann. Trop. Ped. J., 15:3-9.

Li F.; Yoshizawa, T. and Luo, X.(2002) : "Aflatoxins and fumonisins in corn from the high incidence area from human hepatocellular carcinoma in Guang $X 1$ ". China Agric. Food Chem. J., 49(8): 4122-26.

Maxwell, S. M.; Familusi, J. B.; Chan M. C. and Hendrickse, R. G. (1994) : "Delection of naphiols and aflatoxins in $\mathrm{Ni}$ gerian cord blood". Ann. Trop. Ped. J., 14:3-5.

Maxwell, S. M. (1998) : "Investigations into the presence of aflatoxins in human body fluids and tissues in relation to child health in the tropics". Ann. Trop. Ped. J., 18:41-6.

Olubuyide, I.; Hart, A.; Akinyinkaar, O.; Maxwell, M. and Nael, E. (1994) : "HBsAg and aflatoxins in sera of rural (Igbo-Ora) and urban (Ibadan) populations in Nigeria". Afr. Med. J., 22.(4): 77-80.

Osman, N.; Abdel Kadit, A.; Moss, M. and Bener, A. (1999): "Aflatoxin contamination of rice in the United Arab Emi- rates". Mycotoxin Res. J., 15:39-43.

Petrson, R. and Ciegler, A. (1976) : "Separation of aflatoxins by two dimentional T.L.C." Chromatog. J., 31:250-57.

Pryzbylski, M. (1975) : "Detection and measurment of aflatoxins using Tri fluroacetic acid". Med. Res. J., 17(1): 888-90.

Sodeindo, O.; Chan, M.; Maxwel, S.; Familusi, J. and Hendrickse, R. (1995) : "Neonatal jaundice, aflatoxins and naphthols: report of a study in Ibadan, Nigeria". Ann. Trop. Ped. J., 15(2):107-13.

Sudakin, D. L. (2004) : Mycotoxins and toxigenic fungi. In: Medical Toxicology Dart, R. C. (Ed.), 3rd edition, Lippincott, Williams and Williams, Philadelphia, P.P. 1714-1716.

Theresa, L. (2002) : Corn in the rat diet. http://www.rmca.org/Articles/corn.htm.

Van Ness, K.; Mcttygth, T. and Eaton, D. (1998): "Identification of amino acid residues essential for high afaltoxin B1-8 and 9 epioxide conjugation activity in class glutathione $S$ transferase through site directed mutagenesis". Toxicol. Appl. Pharmacol. J., 152:166-74.

Wayne, W. D. (1995) : Biostatistics. In: A Foundation For Analysis in the Health Sciences. 6th ed., John Wiley and 
Suns press, P.P.158-62.

Whitington P. F. and Alonso E. M. (2003) : Measurement of billirubin. In: Hematology of Infancy and Childhood. Nathan, D.G.; Orkin, S.H.; Ginsburg, D.; Oski, N. (Eds.), 6th ed., Philadelphia Press, WB Saunders Co, P.P. 86-112.
Wild, C.; Rasheed, F. and Jawla, M. (2001): "In utero exposure to aflatoxins in West Africa". Lancet J., 337:1602-7.

Wild, C. and Turner, P. (2002): "The toxicology of aflatoxins as a base for public health decisions". Mutagenesis J., 6(6): 471-81. 


\title{
تأثير الأفلاتوكسين على إنتشار اليرقان بدديثى الولادة فى محافظة القليوبية بمسر اليفر بـان
}

\author{
المُشتركرن فى البهث
}

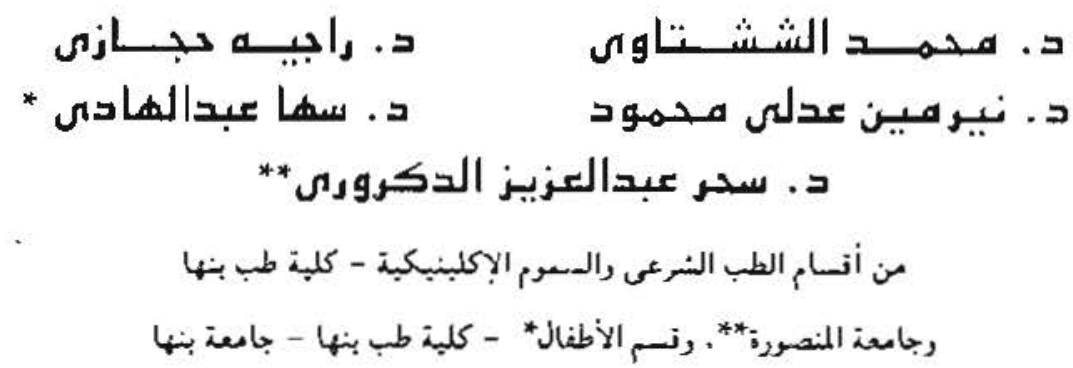

يعتبر الأفلاتوكسين مادة سامة ملوثة للبينة فى البلدان النامبة الاستوأنية، ربرجد منه أكثر من نوع منل B1, M2, M1 ، الذلل تم

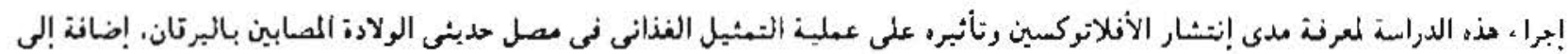

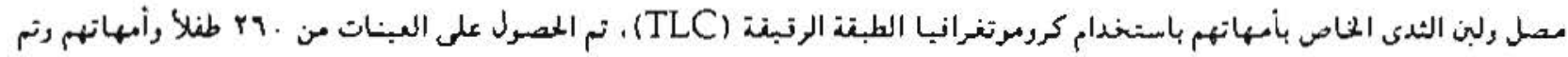

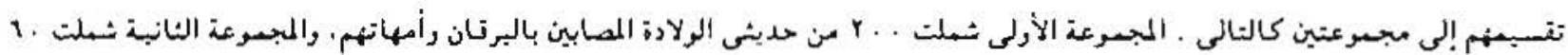

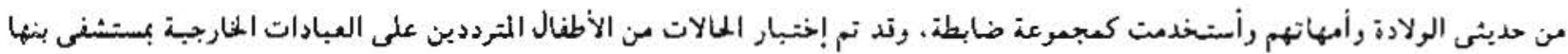

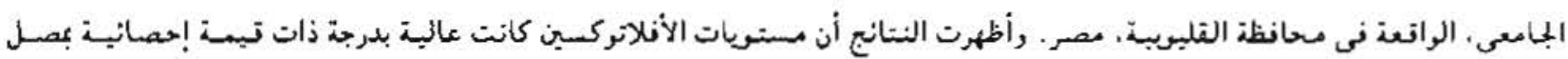

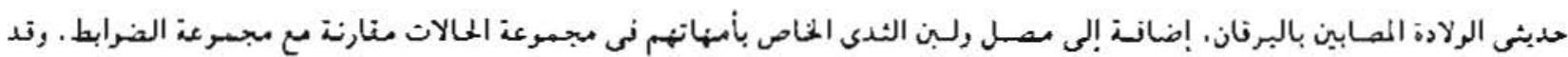

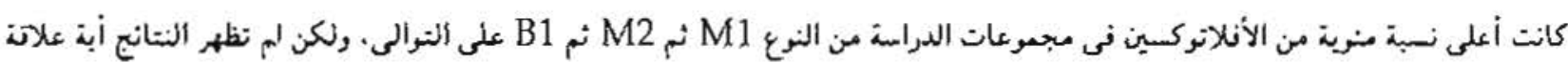

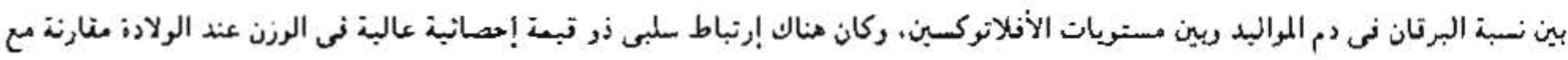

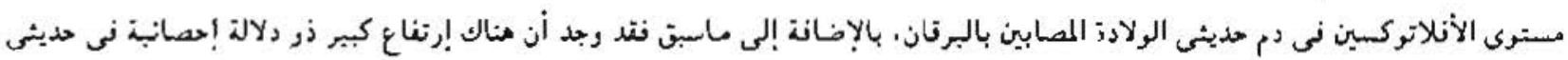

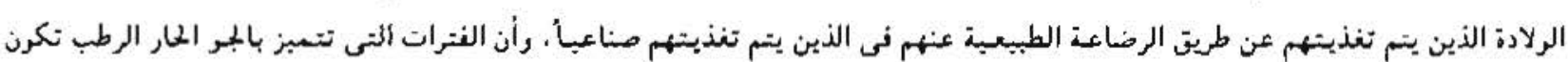

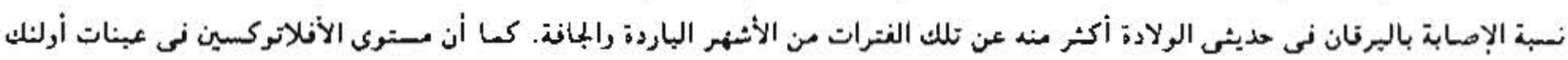

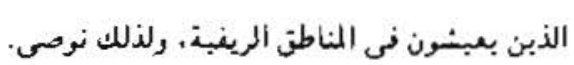

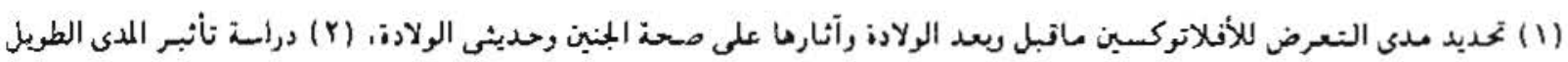

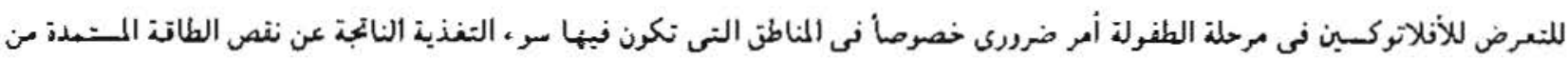

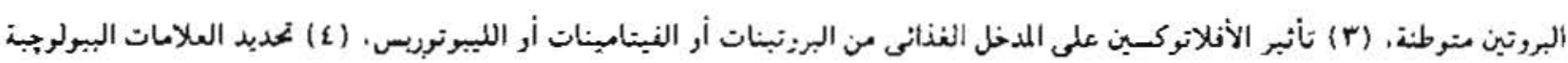

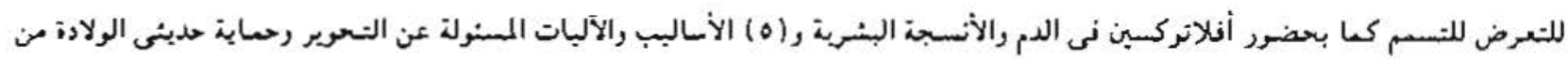
التعرض للأفلاثركسين. 


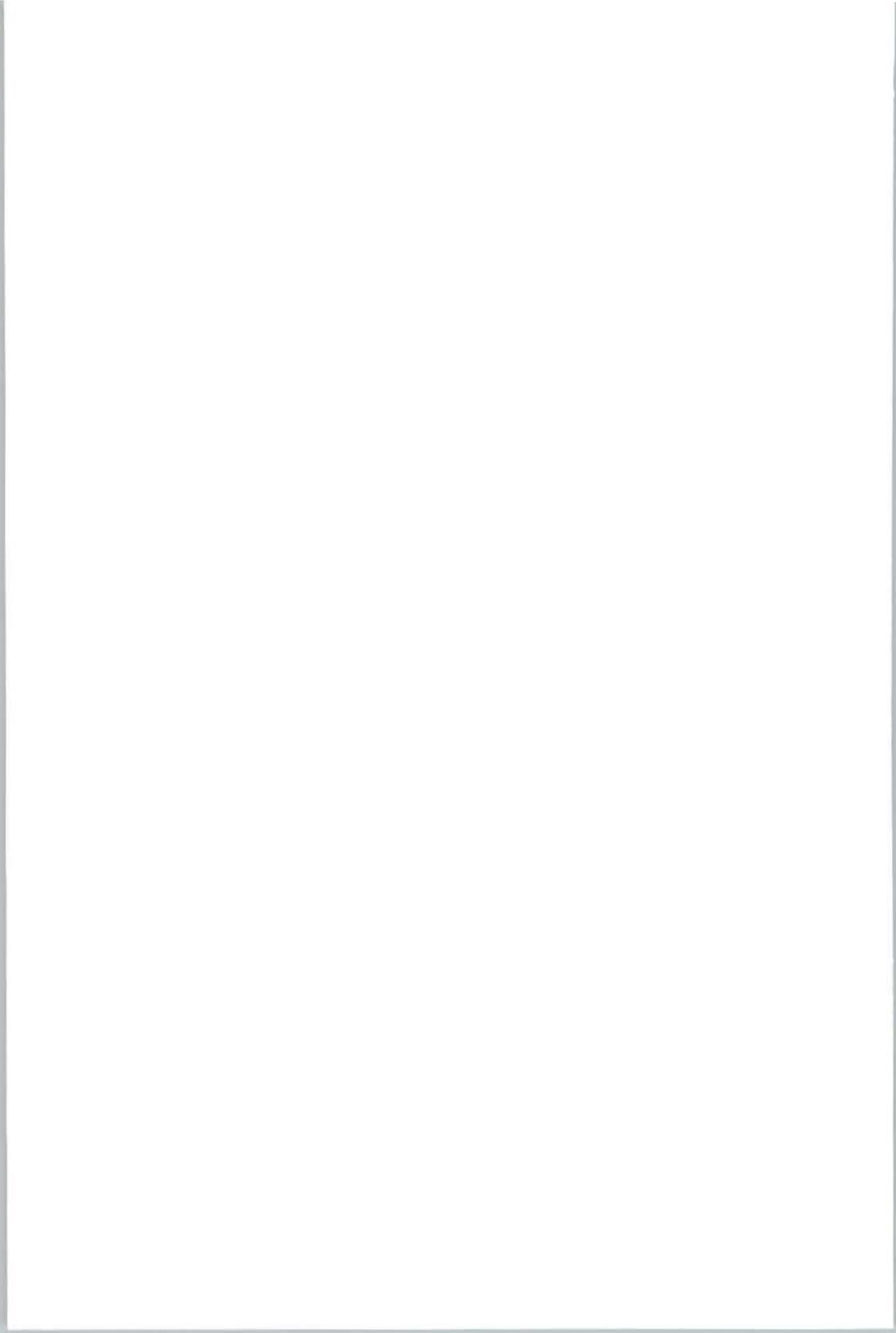

